\title{
Penerapan Model Pembelajaran Tipe Kooperatif Team Assistend Individualization (TAI) untuk Meningkatkan Prestasi Belajar Siswa
}

\author{
Suparti \\ SD Negeri Kalisube UPK Banyumas \\ J1. Jaya Serayu No.66, Karangkamal, Kalisube, Kec. Banyumas, \\ Kabupaten Banyumas, Jawa Tengah \\ Email: bdmartono7@gmail.com
}

\begin{abstract}
Abstrak
Dalam kegiatan pembelajaran banyak faktor yang menentukan keberhasilan belajar, tidak hanya dari peserta didik saja tetapi dari faktor guru dan metode pembelajaran yang digunakan. Penyampaian materi yang membosankan akan membuat peserta didik banyak yang tidak termotivasi dalam proses pembelajaran sehingga membuat hasil belajar / prestasi belajar rendah, hal ini juga terjadi di SDN Kalisube Kelas Vl Semester I tahun pelajaran 2016/2017. Untuk meningkatkan motivasi dan prestasi belajar peserta didik, guru menerapkan dan menggunakan model pembelajaran Kooperatif Tipe Team Assisted Individualization ( TAI ) pada mapel IPA Kompetensi Dasar membandingkan sifat kemampuan menghantarkan panas dari berbagai benda. Penelitian tersebut dibagi menjadi dua siklus.

Setelah dilakukan penelitian hasil yang diperoleh peserta didik adalah, pada studi awal menunjukkan hanya 3 anak atau $15 \%$ dari 20 peserta didik. yang tuntas belajarnya, hal ini jauh di atas kriteria yang ditetapkan yaitu minimal $90 \%$ peserta didik tuntas dari jumlah seluruh peserta didik, pada siklus I ada $65 \%$ atau 13 peserta didik yang tuntas, siklus 2 ada $100 \%$ atau 20 peserta didik yang sudah tuntas belajarnya, Nilai rata-rata yang diperoleh pada studi awal 62 dan pada siklus I meningkat menjadi 75 pada siklus II nilai tara-rata 87.

Dilihat dari perolehan hasil belajar dapat diartikan bahwa Model Pembelajaran model pembelajaran Kooperatif Tipe Team Assisted Individualization (TAI) mempunyai dampak yang positif terhadap proses pembelajaran. Peserta didik lebih termotivasi untuk belajar, lebih aktif dan ketuntasan belajar meningkat. Dengan demikian hipotesis yang peneliti ajukan dalam penelitian tindakan Kelas ini " terbukti"
\end{abstract}

Kata Kunci : prestasi belajar, model pembelajarn Kooperatif Tipe Team Assisted Individulization

Abstract

In learning activities there are many factors that determine learning success, not only from students, but also from the teacher and the learning methods used. Submission of boring material will make many students unmotivated in the learning process so as to make learning outcomes / learning achievements low, this also happens in SDN Kalisube Class Vl Semester I 2016/2017 school year. To increase students' motivation and learning achievement, the teacher applies and uses the Team Assisted Individualization (TAI) Cooperative learning model in the Science Basic Competency map comparing the nature of the ability to conduct heat from various objects. The study was divided into two cycles.

After conducting research the results obtained by students are, in the initial study showed only 3 children or $15 \%$ of 20 students. completed learning, this is far above the established criteria that is a minimum of $90 \%$ of students completed from the total number 
of students, in cycle I there were $65 \%$ or 13 students who completed, cycle 2 there were $100 \%$ or 20 students who had already completed study, the average value obtained in the initial study 62 and in the first cycle increased to 75 in the second cycle an average value of 87.

Judging from the acquisition of learning outcomes can be interpreted that the Learning Model Cooperative learning model Type Team Assisted Individualization (TAI) has a positive impact on the learning process. Students are more motivated to learn, more active and mastery learning increases. Thus the hypothesis that the researcher proposes in this Class action research is "proven"

Keywords: learning achievement, Cooperative learning model Team Assisted Individulization Type (TAI)

\section{PENDAHULUAN}

Keberhasilan dunia pendidikan bukan hanya dapat dilihat di jenjang perguruan tinggi. Tetapi juga di jenjang pendidikan dasar. Keberhasilan pendidikan dipengaruhi oleh faktor guru sebagai pendidik juga pengajar. Guru yang profesional akan selalu berusaha dan berupaya untuk meningkatkan pemahaman peserta didik terhadap materi-materi yang akan diajarkan. Dalam rangka upaya meningkatkan prestasi hasil belajar peserta didik, guru juga harus berupaya meningkatkan proses belajar, menciptakan strategi yang cocok, menerapkan berbagai metode dan model pembelajaran. Metode dan model pembelajaran akan sangat berpengaruh terhadap aktvitas siswa dalam belajar karena belajar merupakan hal yang komplek, hal ini dapat dilihat pada mata pelajaran llmu Pengetahuan Alam bagi peserta dan guru. Dari segi peserta didik, belajar sebagai suatu proses di mana peserta didik mengalami proses mental dalam menghadapi bahan ajar. Dari guru, proses belajar tersebut tampak sebagai perilaku suatu hal. Belajar akan lebih berhasil bila diketahui tujuan yang ingin dicapai. Salah satu tujuannya adalah untuk memperoleh pengetahuan dan mengatasi berbagai kelemahan dan kekurangan adalah dengan menerapkan model pembelajaran yang tepat.

Fakta membuktikan bahwa di Sekolah Dasar Negeri Kalisube rendahnya prestasi belajar pada mata pelajaran IPA disebabkan pembelajaran yang cenderung monoton, hanya ceramah saja sehingga proses pembelajaran hanya berjalan satu arah saja, dan masih menggunakan model pembelajaran lama, di mana proses belajar mengajar hanya terpaku pada guru, peserta didik hanya bisa menerima materi yang disampaikan oleh guru. Sistem pembelajaran tersebut kurang mendorong peserta didik untuk berfikir secara mandiri, cenderung hanya mengikuti petunjuk atau kehendak guru sehingga kurang melatih peserta didik untuk mencoba berbagai alternatif memecahkan masalah dan ini berpengaruh terhadap hasil belajarnya. Berdasarkan uraian masalah tersebut maka 
dibuatlah rumusan masalah "Apakah penerapan model pembelajaran Kooperatif Tipe Team Assisted Individualization (TAI) dapat meningkatkan prestasi belajar peserta didik tentang materi konduktor dan Iisolator pada Kelas V1 SD Negeri Kalisube semester 1 tahun pelajaran 2015/2016.

Beberapa kajian teori yang relevan dalam penelitian ini antara lain:

\section{Pembelajaran Kooperatif Tipe TAI ( Team Assisted Individualization )}

Model pembelajaran Kooperatif Tipe Team Asissted Individualization (TAI) di mana peserta didik dikelompokkan ke dalam kelompok kecil ( 5 peserta didik) secara heterogen yang dipimpin oleh seorang ketua kelompok yang mempunyai lebih di antara anggotanya. Selain itu guru mempunyai fleksibilitas untuk berpindah dari kelompok ke kelompok atau dari individu ke individu, kemudian para peserta didik dapat saling memriksa hasil kersa mereka, mengidentifikasi masalah-masalah dalam kelompok dan dapat ditangani sendiri maupun dengan bantuan guru apabila diperlukan.

Miftahul (2011) mengemukakan bahwa dalam model pembelajaran Kooperatif Tipe Team Asissted Individualization (TAI), peserta didik dikelompokkan berdasarkan kemampuan yang beragam. Masing-masing kelompok terdiri dari 5 peserta didik yang ditugaskan untuk menyelesaikan materi pembelajaran atau PR. Dalam model pembelajaran Kooperatif Tipe Team Asissted Individualization (TAI) setiap kelompok diberi serangkaian tugas tertentu untuk dikerjakan bersama-sama. Point-point dalam tugas dibagi secara berurutan kepada setiap anggota (misalnya, untuk materi Ilmu Pengetahuan Alam yang terdiri dari 8 soal, berarti 4 anggota dalam setiap kelompok harus saling bergantian menjawab soal-soal tersebut). Semua anggota harus saling mengecek jawaban temanteman satu kelompoknya dan saling memberi bantuan jika memang dibutuhkan. Setiap kelompok harus saling memastikan bahwa semua anggotanya paham dengan materi yang telah didiskusikan.

\section{Langkah-langkah Pembelajaran Kooperatif Tipe TAI (Team Assisted Individualization)}

a) Guru memberikan tugas kepada peserta didik untuk mempelajari materi pembelajaran secara individual yang sudah disiapkan oleh guru.

b) Guru memberikan kuis (pretest) secara individu kepada peserta didik untuk mendapatkan skor dasar atau skor awal.

c) Guru membentuk beberapa kelompok. Setiap kelompok terdiri dari 4-5 peserta didik dengan kemampuan (tinggi, sedang, rendah). Jika mungkin anggota kelompok berasal dari ras, budaya, dan suku yang berbeda serta kesetaraan jender. 
d) Hasil belajar peserta didik secara individual didiskusikan dalam kelompok. Setiap anggota kelompok saling memeriksa jawaban teman satu kelompok.

e) Guru memfasilitasi peserta didik dalam membuat rangkuman, mengarahka, dan memberikan menegasan terhadap materi yang telah dipelajari.

f) Guru memberikan kuis (posttest) kepada peserta didik secara individual.

g) Guru memberikan penghargaan kepada kelompok berdasarkan perolehan nilai peningkatan hasil belajar individual dari skor dasar ke skor kuis berikutnya (terkini)

\section{Pengertian Prestasi Belajar}

Menurut Vernon S. Gerlach \& Donal P.Ely dalam Arsyad (2011 : 3) mengemukakan bahwa "belajar adalah perubahan perilaku sedangkan perilaku itu sendiri adalah tindakan yang dapat diamati. Dengan kata lain perilaku adalah suatu tindakan yang dapat diamati atau hasil yang diakibatkan oleh tindakan atau beberapa tindakan yang dapat diamati. Winkel ( 1998 : 15 ) mengemukakan bahwa semua aktivitas mental atau psikis yang berlangsung dalam ineraktif dalam lingkungan, yang menghasilkan perubahanperubahan dalam pengelolaan pemahaman. Menurut Ernest R Hilgard dalam (Sumardi Suryabrata, 1984:252) belajar merupakan proses perbuatan yang dilakukan dengan sengaja, yang kemudian menimbulkan perubahan, yang keadaannya berbeda dari perubahan yang ditimbulkan oleh lainnya. Sifat perubahannya relatif permanen tidak akan kembali kepada keadaan semula. Tidak bisa diterapkan pada perubahan akibat situasi sesaat, seperti perubahan akibat lelah, sakit, mabuk, dan sebagainya

\section{a) Konduktor dan Isolator}

Konduktor atau penghantar adalah zat atau bahan yang bersifat menghantarkan energi, baik energi listrik maupun energi kalor, baik berupa zat padat, cair, atau gas. Bahan-bahan yang bersifat konduktor ini biasanya digunakan untuk membuat alat-alat yang sifatnya membutuhkan kecepatan transfer energi, misalnya panci, setrika, kabel, dan solder.

Isolator listrik adalah bahan yang tidak bisa atau sulit melakukan perpindahan muatan listrik. Isolator dapat diartikan sebagai benda-benda yang tidak dapat atau sukar menghantarkan panas. 


\section{Kerangka Berfikir}

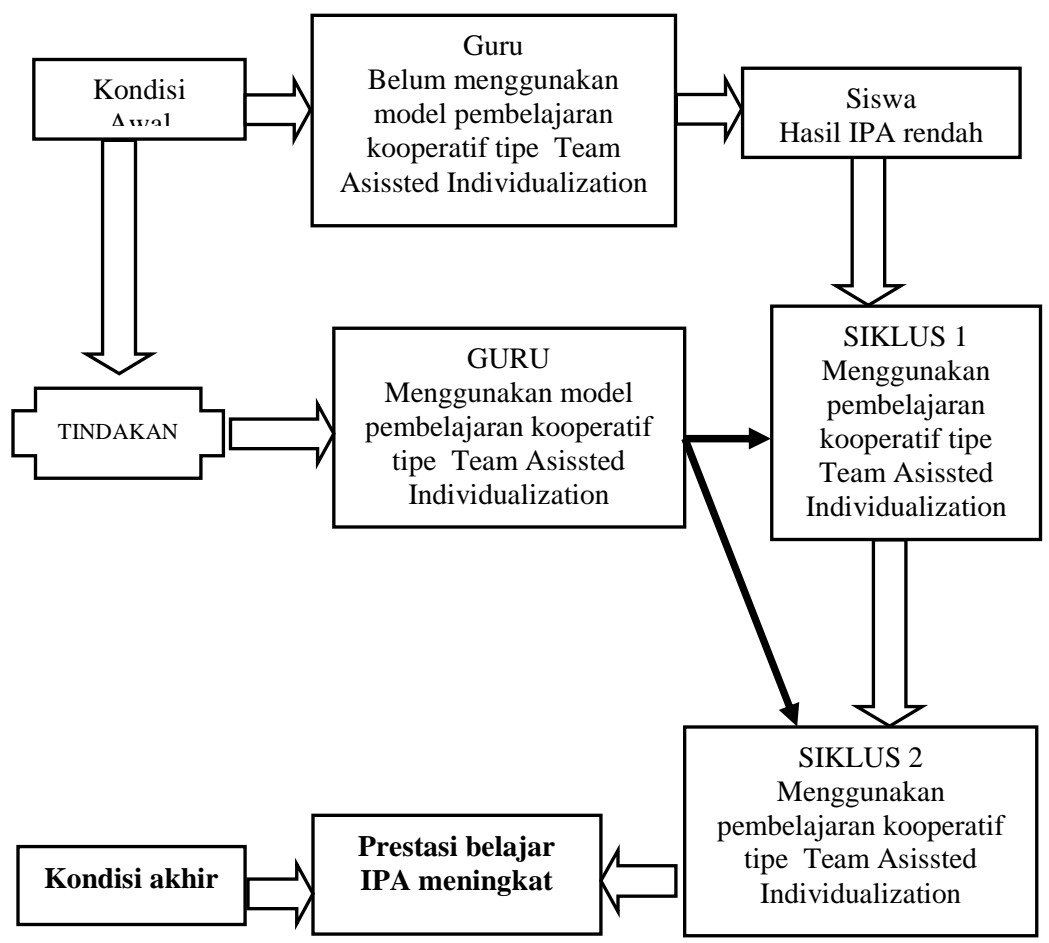

\section{METODE PENELITIAN}

\section{Setting penelitian/lokasi penelitian}

Tempat penelitian adalah SD Negeri Kalisube Unit Pendidikan Kecamatan banyumas Kabupaten Banyumas. Waktu penelitian dilakukan pada semester 1 tahun 2015/2016. Pada bulan Juli sampai dengan bulan Desember 2015. Subyek penelitian adalah peserta didik kelas VI.A SD Negeri Kalisube UPK Banyumas, sebanyak 20 peserta didik terdiri dari 11 peserta didik laki-laki dan 9 peserta didik. Variabel penelitian adalah Model Pembelajarn Kooperatif Tipe Asissted Individulization dan Prestasi Belajar IPA.

Desain Penelitian
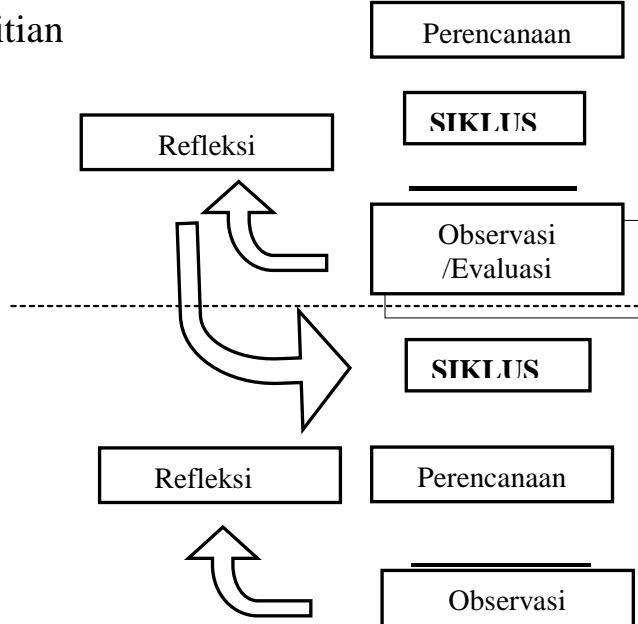

Perencanaan

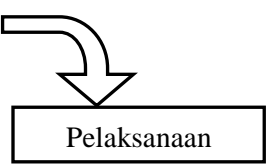

Pelaksanaan

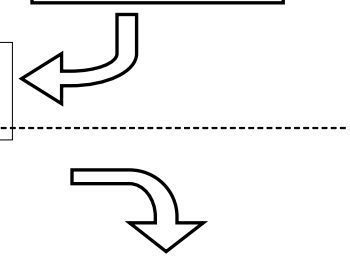

Pelaksanaan

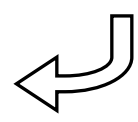




\section{Alat pengumpul data}

1. Lembar Pengamatan, Lembar pengamatan digunakan untuk mengumpulkan data variable proses pembelajaran model Kooperatif Tipe Team Asissted Individualization.

2. Pedoman Wawancara, Pedoman wawancara digunakan untuk mengetahui data tanggapan peserta didik terhadap model pembelajaran telah dilaksananan pada siklus 1 dan siklus 2 .

3. Lembar Evaluasi Tes Kemampuan, Untuk mengetahui hasil peserta didik dalam pembelajaran menggunakan metode Kooperatif Tipe Asissted Indivudalization (TAI) pada peserta didik menggunakan instrumen lembar evaluasi tes kemampuan siklus 1 dan siklus 2 mengacu pada materi pembelajaran yang telah dilaksanakan.

\section{Tehnik Pengumpul Data}

1. Tehnik Pengamatan/Observasi, Observasi/pengamatan digunakan untuk mengumpulkan data tentang proses pembelajaran dan perubahan prilaku peserta didik SD Negeri Kalisube yang dilakukan selama kegiatan pembelajaran berlangsung menggunakan model pembelajaran Kooperatif Tipe Team Asissted Indivudalization (TAI).

2. Tehnik Tes, Tehnik tes dilakukan pada akhir kegiatan pembelajaran menggunakan lembar soal.

3. Tehnik Angket, Untuk mengetahui tanggapan peserta didik setelah melaksanakan kegiatan pembelajaran dengan menggunakan model pembelajaran Kooperatif Tipe Asissted Indivudalization (TAI) peneliti menggunakan tehnik instrumen angket pada siklus 1 dan 2.

4. Tehnik Analisis Data, Tehnik analisis data yang digunakan dalam ada yang bersifat kuantitatif dan ada juga yang bersifat kualitatif .

\section{HASIL DAN PEMBAHASAN}

Berdasarkan nilai hasil belajar pada kondisi awal, siklus 1 dan siklus 2 telah terbukti dengan menggunakan metode pembelajaran Kooperatif Tipe Team Assisted Individualization (TAI) dapat meningkatkan prestasi belajar terutama pada mata pelajaran IPA tentang Konduktor dan isolator panas. Peningkatan prestasi hasil belajar inipun diikuti dengan peningkatak aktivitas peserta didik dari kondisi awal, siklus 1 dan siklus 2 yang sangat memuaskan. Hal ini dapat dilihat pada tabe di bawah ini: 


\begin{tabular}{|l|c|c|c|c|c|c|c|}
\hline \multirow{2}{*}{ No } & \multirow{2}{*}{$\begin{array}{c}\text { Aktivitas } \\
\text { peserta didik }\end{array}$} & $\begin{array}{c}\text { Sebelum Perbaikan } \\
\text { Jumlah }\end{array}$ & \multicolumn{2}{c|}{ Siklus 1 } & \multicolumn{2}{c|}{ Siklus 2 } \\
\hline 1 & Terlibat aktif & 2 & $\begin{array}{c}\text { Jumlah } \\
\text { peserta didik }\end{array}$ & $\%$ & $\begin{array}{c}\text { Jumlah peserta } \\
\text { didik }\end{array}$ & $\%$ \\
2 & Terlibat pasif & 10 & $50 \%$ & 14 & $70 \%$ & 20 & $100 \%$ \\
3 & Tidak terlibat & 8 & $40 \%$ & 2 & $10 \%$ & 0 & $0 \%$ \\
& Jumlah & 20 & $100 \%$ & 20 & 100 & 20 & $100 \%$ \\
& & & & $\%$ & & \\
\hline
\end{tabular}

Dari data di atas aktivitas belajar peserta didik mengalami peningkatan yang sangat signifikan terutama pada kondisi awal hanya 2 dari 20 peserta didik atau $10 \%$, pada siklus 2 meningkat menjadi 14 peserta didik atau $70 \%$ hingga siklus 3 semua peserta didik terlibat secara aktif dalam pembelajaran sehingga 20 peserta didik terlibat secara aktif atau $100 \%$.

\section{KESIMPULAN}

Penelitian Tindakan Kelas (PTK) untuk meningkatkan pemahaman siswa tentang konduktor dan isolator dengan menggunakan model pembelajaran Kooperatif Tipe Team Assisted Individualization ( TAI ) dalam pembelajaran Ilmu Pengetahuan alam (IPA) di kelas VI SDN Negeri Kalisube kelurahan Kalisube Kecamatan Banyumas berdasarkan hasil penelitian dapat disimpulkan sebagai berikut :

1. Pelaksanaan pembelajaran tentang Konduktor dan Isolator dengan menggunakan model pembelajaran Kooperatif Tipe Team Assisted Individualization (TAI) berjalan dengan sekenario yang ada pada Rencana Pelaksanaan Pembelajaran (RPP) dan telah berhasil menciptakan situasi belajar yang kondusif yakni siswa terlibat secara langsung pada proses pembelajaran, juga dapat meningkatkan motivasi siwa untuk belajar Ilmu Pengetahuan Alam yang semula dianggap sulit.

2. Tingkat pemahaman siswa tentang konduktor dan isolator dengan menggunakan model pembelajaran Kooperatif Tipe Team Assisted Individualization (TAI) dapat meningkat dengan baik, ini dapat dilihat dari hasil evaluasi yaitu nilai rata-rata pada kondisi awal 62, tuntas 15\%, tidak tuntas $85 \%$, terjadi kenaikan pada siklus 1 nilai rata-rata 75 , tuntas $65 \%$, tindak tuntas $35 \%$ dan siklus 2 terjadi kenaikan yang sinifikan yaitu nilai rata-rata menjadi 87 , tuntas $100 \%$ dan tidak tuntas $0 \%$. 


\section{SARAN}

Pada penelitian berikutnya, perlu pengembangan berbagai model pembelajaran kooperatif untuk meningkatkan prestasi dan belajar siswa.

\section{DAFTAR PUSTAKA}

Badan Nasional Pendidikan. (2006) Panduan Penyusunan Kurikulum Tingkat Satuan Pendidikan Jenjang Pendidikan Dasar dan Menengah:BSNP

Depdiknas, (2004). Kurikilum Pendidikan Dasar, Dirjen Dikdasmen

Depdikbud, (2002). Ilmu Pengetahuan AlamPetunjuk Guru Sekolah Dasar Kelas 6 Dirjen Pendidikan. Jakarta Dirjendikdasmen.

Kasiano Kasbolah, (1991). Penelitian Tindakan Kelas Dirjen Pendidikan Tinggi, Proyek Pendidikan Sekolah Dasar.

Nana Sujana, (2002) Media Pengajaran Pusat Penelitian dan Pembidangan Ilmu Lembaga Penelitian IKIP Bandung, Sinar Baru.

Ngalimun Purwanto, (2012) Psikologi Pendidikan Bandung Remaja Rosda Karya. 